\title{
Relationship between ciliates and environmental parameters in a restored carbonate fen
}

\author{
Tomasz MIECZAN,${ }^{1 *}$ Małgorzata ADAMCZUK,${ }^{1}$ Aleksander ŚWIĄTECKI,${ }^{2}$ Natalia RUDYK-LEUSKA ${ }^{3}$ \\ ${ }^{1}$ Department of Hydrobiology and Protection of Ecosystems, University of Life Sciences, Dobrzańskiego 37, 20-262 Lublin, Poland; \\ ${ }^{2}$ Department of Microbiology and Mycology, University of Warmia and Mazury, Oczapowskiego 1A, 10-719 Olsztyn, Poland; \\ ${ }^{3}$ Department of Hydrobiology and Ichthyology, National University of Life and Environmental Sciences of Ukraine, General \\ Rodimtsev 19, Kiev, Ukraine
}

\begin{abstract}
Wetlands restoration has been implemented on sites exploited for agricultural for over a decade in Eastern Europe. However, little is known about microbial diversity in this region. Microbial processes and patterns can be used as sensitive indicators of changes in environmental conditions. The responses of ciliates wetlands restoration are largely unexplored. Based on the results of a long-term study in fen of the Poleski National Park (Poland), we assumed that restoration causes changes in the physicochemical properties of fen water and sought to answer the question of how ciliate communities react to these changes and whether these microorganisms can play a significant role as bioindicators in evaluating the restoration process. Twenty taxa were recorded in the ciliate community, with 16 taxa found prior to restoration and 12 after restoration. Restoration clearly modified the taxonomic composition and abundance of ciliates. This was reflected in a decrease in the abundance and in the density of these protozoa and in a significant increase in the proportion of euplanktonic species. Before restoration, the most common ciliates were Cinetochilum margaritaceum and Strombidium viride, while the proportion of Paramecium bursaria increased after restoration. We also observed that the improvement in hydrological conditions, and hence the transformation of the vegetation structure in the peat bog, causes changes in the trophic structure of ciliates. The RDA analysis showed that all variables together accounted for $86.9 \%$ of the total variance. However, variables that significantly explained the variance in ciliate communities were water level, temperature, $\mathrm{pH}$, and nutrients. Our results suggest that an indicator species approach based on functional groups may be appropriate for biomonitoring fens restoration.
\end{abstract}

\section{INTRODUCTION}

Wetlands play an integral role in the hydrologic cycle, and provide important ecosystem services that may include flood storage, water quality amelioration and enhancement, carbon storage, wildlife habitat, and buffers during periods of high water (Robson et al., 2005). Irrespective of the type of wetlands, these ecosystems are among the fastest disappearing and most endangered ecosystems in Europe, which is especially disquieting in light of progressive climate warming (Robson et al., 2005; Bragazza et al., 2006). Among the most valuable

Corresponding author: tomasz.mieczan@up.lublin.pl

Key words: Biodiversity; peatbog; biomonitoring; protozoa.

Edited by: Francesca Bona, University of Turin, Italy

Received: 26 October 2018.

Accepted: 16 January 2019.

This work is licensed under a Creative Commons Attribution NonCommercial 4.0 License (CC BY-NC 4.0).

CCopyright T. Mieczan et al., 2019

Licensee PAGEPress, Italy

J. Limnol., 2019; 78(1): 107-120

DOI: 10.4081/jlimnol.2019.1867 ecosystems are carbonate fens. These are low peatbogs on a substrate very rich in calcium carbonate and fed by calcium-rich waters, mainly overgrown by Cladium mariscus and often in contact with mosses and sedges, with a significant share of calciphilous plants. The water table is usually above the land surface and is subject to seasonal fluctuations. In terms of fertility, they are predominantly mesotrophic peatlands (European Commission, 2013). These are priority natural habitats, which means that their survival in the Europe Union depends on taking specific, adequate conservation measures. The implementation of these plans is difficult because knowledge of the resources of the habitat, how well it has been preserved, local ecological conditions and proper means of maintaining and protecting it is still inadequate. Many wetlands have been drained for agriculture or mined for peat, which has greatly altered their plant communities (McCormac and Schneider, 1994). Other human actions affecting wetlands include afforestation, acid rain, agricultural pollution and use as landfill sites (Headley et al., 1992; Creevy et al., 2018). The drainage and harvesting of wetlands alter nutrient dynamics and affect microbial communities (Andersen et al., 2013). The removal of vegetation cover and lowering of the water table exposed humified substrate and poorquality organic matter to aerobic conditions, thus hindering microbial activity (C-limitation) because much of the $\mathrm{C}$ is refractory (Bayley et al., 2005). Methods aimed to restore wetlands (i.e., peatbogs) have been developed 
and tested for over decade and recent studies have shown that typical bog vegetation can quickly become dominant following restoration (Poulin et al., 2012). However, peat formation and carbon sequestration also depend on belowground processes that regulate organic matter turnover and affect the vegetation responses. Therefore, assessing the long-term success of wetlands restoration requires evaluating if nutrient pool change over time and if microbial communities develop towards natural conditions under the grooving vegetation. Thus far, the vast majority of studies evaluating the effects of restoration have mainly concerned the impact of modification of hydrological conditions on vegetation and testate amoebae (Poulin et al., 2012; Andersen et al., 2013; Marcisz et al., 2014). Testate amoebae abundance and community structure were also shown to respond to peatland drainage (Warner and Chmielewski, 1992). There is no information, however, on how improvement of the hydrological conditions of fens may affect the occurrence of ciliates. Research conducted thus far has mainly concerned the effect of an increase in the content of biogenic compounds on primary producers and protists in peat ponds in Germany (Pfister et al., 2002). The literature on microbial ecology contains almost no information on the application of ciliates in assessment of peatland restoration (Elliott et al., 2015). However, the microbial community may be more sensitive or respond more readily to changes in hydrological conditions and trophic status than in the case of vegetation (Wright et al., 2009; Andersen et al., 2013; Marcisz et al., 2014; Mieczan et al., 2015, 2018). Ciliates are known to be an important food source for metazoa and effectively transfer primary production to higher trophic levels. They can feed on bacteria, auto- and heterotrophic pico- and nanoplankton and provide dissolved organic material (DOM) as nutrients to bacteria (Gilbert et al., 1998a, 1998b; Wilkinson and Mitchell, 2010; Mieczan et al., 2012). Studies suggest that the most important factors limiting the occurrence of ciliates in wetlands are water table depth, $\mathrm{pH}$ and nutrients (Nguyen-Viet et al., 2007; Mieczan et al., 2012). Little is known of how long-term variability of environmental conditions may influence ciliate community composition in fens. The primary objective of the present study was, therefore, to determine the dynamics of ciliates in restored carbonate fen. Based on the results of long-term research (10 years), we have attempted to answer the question of how ciliate communities respond to changes in the hydrological conditions and physicochemical properties of carbonate fens that have undergone restoration processes.

The following hypotheses were tested: H1, Changes in hydrological conditions modify the physicochemical properties of water and the species composition of vegetation in carbonate fens, and in consequence affect ciliate communities; H2, Ciliates are sufficiently specific (i.e. differ between the lagg and central part of the fen) and responsive (i.e. affected by disturbance and restoration) to be used as a bio-indicators in fens undergoing degraded-to-natural bog restoration.

\section{METHODS}

\section{Study site}

A study of the effect of restoration processes on the functioning of ciliate communities was carried out in the carbonate-rich fen Bagno Bubnów (Poleski National Park, eastern Poland, $51^{\circ} \mathrm{N}, 23^{\circ}$ E, Fig. 1). In the 1960s and 1970 s this area underwent intensive drainage procedures, which led to a decline in the groundwater and surface water level and to mineralization of the peat. This was reflected in degradation of the vegetation cover, mainly the appearance of vegetation characteristic of eutrophic habitats, including Molinio-Arrhenatheretea and Phragmites australis (Car.). Since the 1990s intensive restoration measures have been conducted in Poleski National Park to improve the hydrological conditions of this area. Restoration of the Bagno Bubnów fen has been carried out systematically since 2006 and has mainly involved the use of dams to raise the water level and the removal of trees and shrubs overgrowing the fen, such as birches, willows and alders, which were present in high numbers on its edges. The vegetation is currently dominated mainly by Cladium mariscus (L.), Carex buxbaumii Wahlenb., Carex acutiformis Ehrhart., Calliergonella cuspidata (Hedw.), Schoenus ferrugineus L., Phragmites australis (Car.) and Utricularia sp. The edge zone of the fen is dominated by Carex acutiformis Ehrhart. and Calliergonella cuspidata (Hedw.), and the central zone by Phragmites australis (Car.) (Tab. 1).

\section{Abiotic variables}

Physicochemical and hydrological properties were tested from 2005 to 2014. Restoration of the fen begun in October 2006. Each year samples of water were collected once a month from April to November from two areas: the lagg zone and the central zone. Each year, water properties measurements (with YSI 556MPS) and water sampling (for Plexiglas corer, length $1.0 \mathrm{~m}, \varnothing 50 \mathrm{~mm}$ ) were collected. Physical and chemical analyses were performed according to Golterman (1969). Each time the following parameters were analysed at each site: temperature, conductivity, $\mathrm{pH}$, dissolved oxygen $\left(\mathrm{O}_{2}\right)$, chlorophyll $a, \mathrm{P}_{\mathrm{tot}}, \mathrm{N}_{\mathrm{tot}}, \mathrm{NH}_{4}^{+}, \mathrm{NO}_{3}^{-}, \mathrm{PO}_{4}{ }^{3-}$ and total organic carbon (TOC). Chlorophyll $a$ concentration was determined by spectrophotometric analysis of ethanol extracts of algae retained on Whatman GF/C filters (1.2 $\mu \mathrm{m}, 4.5 \mathrm{~cm}$ diameter). The absorbance of the chlorophyll 
extract was measured at 665 and $750 \mathrm{~nm}$ with the SPECORD 40 spectrophotometer. Calculation of chlorophyll $a$ was based on the equations reported in Marker et al. (1980). Total organic carbon (TOC) analysis was performed using wet potassium persulfate digestion with an O/I Corporation Model 700 TOC analyser. Temperature, conductivity, $\mathrm{pH}$ and DO were assessed with a multiparametric probe (YSI 556MPS).

\section{Ciliate communities}

Fieldwork was done monthly from April to November 2005-2014. Ciliate samples were collected once a month from April to November from two areas: the lagg zone and the central zone. The sampling sites consisted of patches $\left(2-4 \mathrm{~m}^{2}\right)$ of various mosses and belts of vascular plants (Phragmites australis, Carex acutiformis Ehrhart., Utricularia sp. and Calliergonella cuspidate). In each type of habitat water was sampled using a Plexiglas corer (length $1.0 \mathrm{~m}, \varnothing 50 \mathrm{~mm}$ ). The Plexiglas corer was closed at each end with a cork and then water samples were collected using a syringe (volume $=100 \mathrm{~mL}, 4-5$ samples $\times 100 \mathrm{~mL}$ ). The volume of water extracted from the Plexiglas corer ranged from 400 to $500 \mathrm{ml}$. The samples were preserved with Lugol's solution directly at the sampling site. Ciliate abundance and community composition were determined by Utermöhl's method (Utermöhl, 1958). After settling for $24 \mathrm{~h}$, each sample was concentrated into $100 \mathrm{~mL}(=5 \times)$, mixed and counted under an inverted microscope (Nikon Eclipse) at $150 \times$ and $600 \times$ magnification by scanning the entire bottom of a 10 mL chamber (Utermöhl, 1958). Additionally, we observed

Tab. 1. Selected ecological features and dominant plant species before (2005-2006) and after restoration (2007-2014) in investigated fen.

\begin{tabular}{|c|c|c|c|}
\hline \multicolumn{4}{|c|}{ Dominant plant species and/or assemblage of plants } \\
\hline Location & Site & Before restoration & After restoration \\
\hline $51^{\circ} 22.364^{\prime} \mathrm{N}, 23^{\circ} 15.303^{\prime} \mathrm{E}$ & Lagg & $\begin{array}{l}\text { Phragmites australis (Car.), } \\
\text { Typha latifolia L., Carex acutiformis Ehrhart. } \\
\text { Alnus glutinosa (L.) Gaertn, Salix L., } \\
\text { Molinio-Arrhenatheretea, Betula sp. }\end{array}$ & $\begin{array}{l}\text { Phragmites australis (Car.), Cladium mariscus (L.), } \\
\text { Carex buxbaumii Wahlenb., Typha latifolia L., } \\
\text { Carex acutiformis Ehrhart., } \\
\text { Molinio-Arrhenatheretea, Utricularia sp., } \\
\text { Calliergonella cuspidata (Hedw.), } \\
\text { Schoenus ferrugineus L. }\end{array}$ \\
\hline $51^{\circ} 22.366^{\prime} \mathrm{N}, 23^{\circ} 15.306^{\prime} \mathrm{E}$ & Central part of fens & $\begin{array}{l}\text { Phragmites australis (Car.), Typha latifolia L., } \\
\text { Carex acutiformis Ehrhart., Salix L. }\end{array}$ & $\begin{array}{l}\text { Phragmites australis (Car.), Typha latifolia L., } \\
\text { Carex acutiformis Ehrhart., Utricularia sp. }\end{array}$ \\
\hline
\end{tabular}
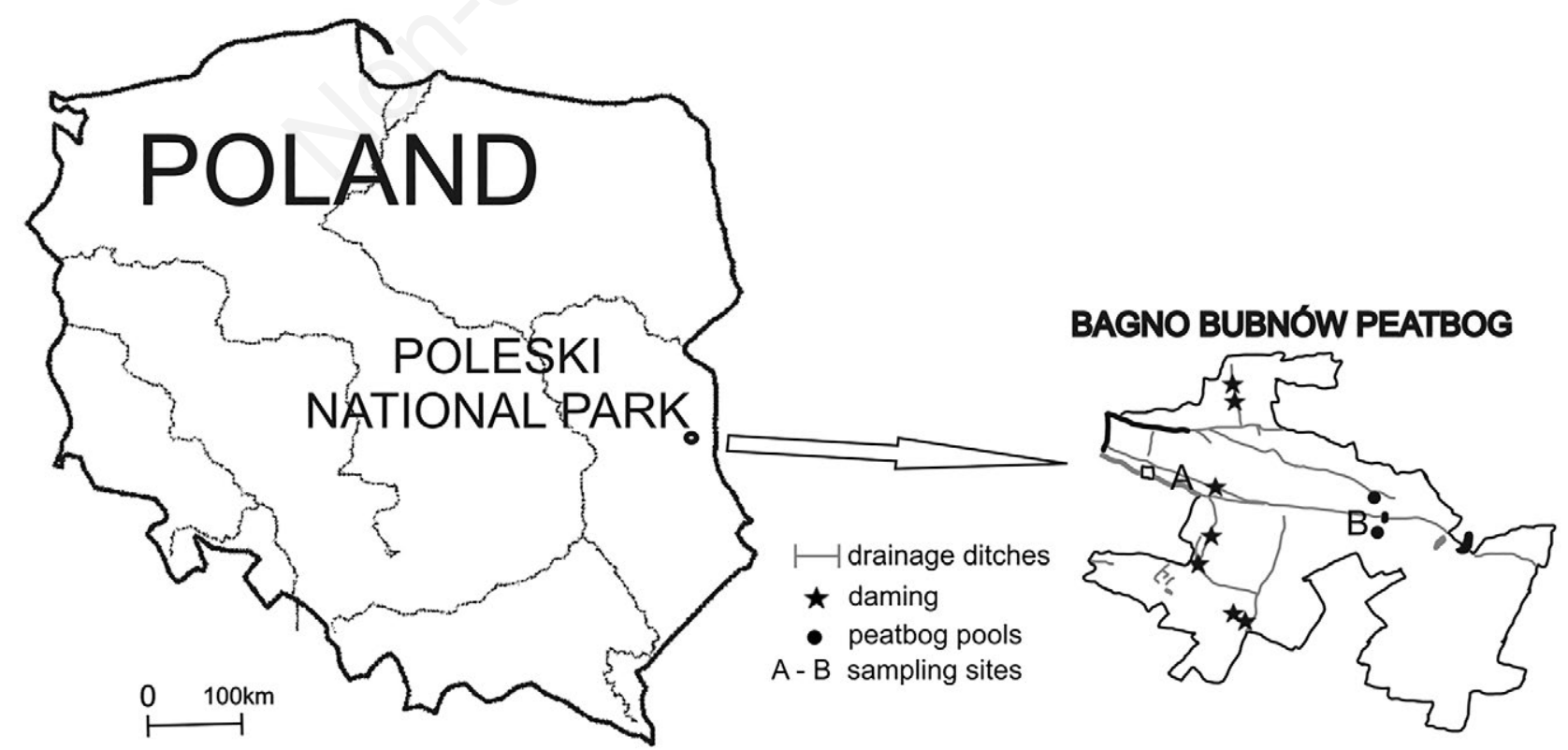

Fig. 1. Location of the investigated fen and study site; A, lagg zone; B, central part. 
live samples. In laboratory, the water was passed through a planktonic mesh with $10 \mu \mathrm{m}$ plankton net to concentrate and separate ciliates from other zooplankton species. Live ciliates were acquired from the sample obtained by filtration of water in laboratory conditions using a stereoscopic microscope and micropipettes. Live samples were observed under a light microscope Nikon TE 200. Morphological identification of ciliates was mainly based on works by Foissner and Berger (1996) and Foissner et al. (1994, 1999). Ciliates were divided into three ecological group depending on their preferred habitat: euplanktonic, benthic and periphytonic (Foissner and Berger, 1996; Karus et al., 2014). Individual ciliates were measured directly and biovolumes were estimated by assuming geometric shapes and converting to carbon using the following conversion factor: $1 \mu \mathrm{m}^{3}=1.1 \times 10^{-7}$

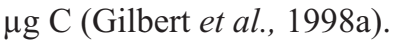

\section{Data analyses}

One-way ANOVA was used to test the effect of restoration on environmental parameters and on the ciliate communities in investigated habitats. Tukey's multiple range test (at $\mathrm{P}<0.05$ ) was used to compare means when significant differences were found. Spearman's correlation coefficients were calculated in order to specify the interactions between species diversity and physical and chemical parameters. Additionally, the rarefaction was used to compare species richness among micro-sites (lagg zone and the central zone), using EcoSim ver. 5.0 (Gotelli and Graves, 1996; Gotelli and Colwell, 2001; Gotelli and Entsminger, 2004). For further macrophytes and ciliate diversity analysis we used the Shannon index H' (Shannon and Weaver, 1949):

$$
H=-\Sigma\left(\mathrm{p}_{\mathrm{i}} \times \ln p_{i}\right)
$$

where $p_{i}$ is the relative proportion of species $i$.

Linear regression analyses were used to determine the relationships between the Shannon index for plants and the number of euplanktonic, benthic and periphytic taxa. As the length of the variability gradients indicated by ciliates was $<2$ standard deviations, principal component analysis (PCA) was performed to confirm the effect of restoration on ciliate communities. Redundancy analysis (RDA) was used to explore the relationships between the density of ciliate species and environmental variables before and after reed removal (ter Braak and Šmilauer, 2002). Prior to PCA and RDA analyses the data were square-root transformed. Automatic forward selection of environmental variables (Monte Carlo permutation test) was used to determine the significant variables. The proportion of variance explained by environmental variables was quantified using variance partitioning. The ordination analyses were performed in CANOCO 4.5 for
Windows. The IndVal approach (Dufrene and Legendre, 1997) was adopted to identify indicator species of fen before and after restoration. Indicator species for each cluster were identified using the 'indval' function in the package 'labdsv' (Roberts, 2010). For each community, taxa with a P-value $<0.01$ and IndVal $>0.30$ were selected as potential indicator species. Statistical analyses were performed with R ( $\mathrm{R}$ Core Team, 2013) using the packages 'vegan' (Oksanen et al., 2012), 'MASS' (Venables and Ripley, 2002) and 'labdsv' (Roberts, 2010).

\section{RESULTS}

\section{Hydrology, physical and chemical parameters}

The water level prior to restoration was significantly lower, at just $6 \mathrm{~cm}$, while after the restoration ranged from 21 to $55 \mathrm{~cm}$ (Tab. 2). Significantly higher values for $\mathrm{pH}$, conductivity, nutrients and total organic carbon were noted before restoration. Statistically significant differences (effect of restoration) within the lagg habitat were found for water level (ANOVA, $\mathrm{F}_{4.200}=2.34$, $\mathrm{P}=0.004, \mathrm{df}=5$ ), temperature (ANOVA, $\mathrm{F}_{4.200}=4.28$, $\mathrm{P}=0.042, \mathrm{df}=6), \mathrm{O}_{2}\left(\mathrm{ANOVA}, \mathrm{F}_{1.400}=4.64, \mathrm{P}=0.034, \mathrm{df}=6\right)$ and TOC (ANOVA, $\mathrm{F}_{4.200}=5.43, \mathrm{P}=0.022, \mathrm{df}=5$ ). Within the central part of fen we observed significant differences for water level (ANOVA, $\mathrm{F}_{4.200}=13.02, \mathrm{P}<0.001$, $\mathrm{df}=6$ ), temperature (ANOVA, $\mathrm{F}_{4.200}=4.47, \mathrm{P}=.038, \mathrm{df}=6$ ), chlorophyll a (ANOVA, $\mathrm{F}_{4.200}=24.31, \mathrm{P}<0.001, \mathrm{df}=6$ ) and $\mathrm{O}_{2}\left(\mathrm{ANOVA}, \mathrm{F}_{4.200}=4.63, \mathrm{P}=0.034 \mathrm{df}=5\right.$ ). Only some pairs of environmental variables are strongly and significantly correlated (Tab. 3). The strongest positive correlation showed $\mathrm{N}-\mathrm{NO}_{3}$ with $\mathrm{P}_{\text {tot }}$. The highest significant negative values of correlation coefficient were calculated for $\mathrm{P}-\mathrm{PO}_{4}$ and $\mathrm{P}_{\text {tot }}$.

\section{Ciliate communities}

Twenty taxa were recorded in the ciliate community, with 16 taxa found prior to restoration and 12 after restoration. The Shannon diversity of the communities varied between 0.98 before restoration and 2.96 after restoration (Fig. 2). A particularly pronounced decline in the number of taxa after the restoration was found in the lagg zone - from 14 taxa to 8, while in the central zone of the fen the decrease was smaller, from 9 ciliate taxa to 6 . Considering lagg and central zone as a single habitat across the entire sampling region, species richness in the lagg was greater than in central part of fen (rarefaction analysis) (Fig. 3). Prior to restoration, the species richness and Shannon diversity index were strongly positively correlated with $\mathrm{pH}(r=0.50-0.76, \mathrm{P}<0.01$, respectively $)$ and concentration of $\mathrm{P}_{\text {tot }}(r=0.53-0.71, \mathrm{P}<0.01$, respectively). Following restoration, the number of ciliate taxa and the Shannon index were strongly positively correlated with 
Tab. 2. Hydrological, physical and chemical parameters of water in investigated peatbog (2005-2006 before restoration; $2007-2014$ after restoration, mean $\pm \mathrm{SD}$ ).

\begin{tabular}{|c|c|c|c|c|c|c|c|c|c|c|}
\hline $\begin{array}{l}\text { Parameters/ } \\
\text { years }\end{array}$ & 2005 & 2006 & 2007 & 2008 & Lagg & 2010 & 2011 & 2012 & 2013 & 2014 \\
\hline Water level $(\mathrm{cm})$ & $6 \pm 2$ & $16 \pm 3$ & $16 \pm 5$ & $17 \pm 7$ & $22 \pm 3$ & $21 \pm 4$ & $8 \pm 2$ & $28 \pm 3$ & $51 \pm 13$ & $50 \pm 12$ \\
\hline Temp. $\left({ }^{\circ} \mathrm{C}\right)$ & $13.5 \pm 2.2$ & $12.3 \pm 3$ & $8.4 \pm 4$ & $12.0 \pm 3$ & $9.0 \pm 2$ & $7.9 \pm 6$ & $8.6 \pm 7$ & $11.9 \pm 5$ & $11.6 \pm 6$ & $9.4 \pm 4$ \\
\hline $\mathrm{pH}$ & $8.5 \pm 1$ & $8.1 \pm 2$ & $8.6 \pm 2$ & $8.8 \pm 1$ & $8.2 \pm 2.2$ & $8.1 \pm 1$ & $7.8 \pm 2.2$ & $7.8 \pm 1$ & $8.3 \pm 2$ & $8.2 \pm 1$ \\
\hline Cond. $\left(\mu \mathrm{S} \mathrm{cm}^{-1}\right)$ & $476.9 \pm 21$ & $272.4 \pm 12$ & $262.4 \pm 11$ & $164.0 \pm 11$ & $183.0 \pm 12$ & $175.0 \pm 23$ & $309.9 \pm 11$ & $201.3 \pm 21$ & $212.5 \pm 21$ & $208.6 \pm 26$ \\
\hline $\mathrm{O}_{2}\left(\mathrm{mg} \mathrm{L}^{-1}\right)$ & $4.4 \pm 1$ & $3.6 \pm 2$ & $3.2 \pm 1$ & $4.8 \pm 1$ & $8.7 \pm 3$ & $8.4 \pm 2$ & $6.2 \pm 2$ & $9.2 \pm 1$ & $7.4 \pm 2$ & $7.0 \pm 2$ \\
\hline $\mathrm{NH}_{4}^{+}\left(\mathrm{mg} \mathrm{L}^{-1}\right)$ & $0.577 \pm 0.12$ & $0.577 \pm 0.02$ & $0.577 \pm 0.11$ & $0.414 \pm 0.32$ & $0.564 \pm 0.21$ & $0.527 \pm 0.13$ & $0.952 \pm 0.11$ & $0.264 \pm 0.11$ & $0.193 \pm 0.04$ & $0.015 \pm 0.01$ \\
\hline $\mathrm{NO}_{3}^{-}\left(\mathrm{mg} \mathrm{L}^{-1}\right)$ & $0.257 \pm 0.07$ & $0.257 \pm 0.11$ & $0.225 \pm 0.03$ & $1.800 \pm 0.34$ & $0.225 \pm 0.05$ & $0.196 \pm 0.05$ & $0.225 \pm 0.08$ & $0.225 \pm 0.12$ & $0.114 \pm 0.06$ & $0.158 \pm 0.08$ \\
\hline $\mathrm{N}_{\mathrm{tot}}\left(\mathrm{mg} \mathrm{L}^{-1}\right)$ & $2.614 \pm 0.03$ & $2.614 \pm 0.23$ & $1.614 \pm 0.34$ & $2.910 \pm 0.24$ & $1.614 \pm 0.05$ & $1.620 \pm 0.08$ & $1.964 \pm 0.34$ & $1.664 \pm 0.45$ & $1.626 \pm 0.28$ & $1.589 \pm 0.67$ \\
\hline $\mathrm{PO}_{4}{ }^{3-}\left(\mathrm{mg} \mathrm{L}^{-1}\right)$ & $0.078 \pm 0.021$ & $0.076 \pm 0.01$ & $0.087 \pm 0.01$ & $0.058 \pm 0.11$ & $0.057 \pm 0.01$ & $0.062 \pm 0.01$ & $0.095 \pm 0.021$ & $0.065 \pm 0.023$ & $0.064 \pm 0.01$ & $0.090 \pm 0.03$ \\
\hline $\mathrm{P}_{\mathrm{tot}}\left(\mathrm{mg} \mathrm{L}^{-1}\right)$ & $0.337 \pm 0.06$ & $0.237 \pm 0.09$ & $0.178 \pm 0.08$ & $0.427 \pm 0.89$ & $0.178 \pm 0.05$ & $0.166 \pm 0.076$ & $0.215 \pm 0.01$ & $0.215 \pm 0.06$ & $0.128 \pm 0.01$ & $0.166 \pm 0.08$ \\
\hline $\begin{array}{l}\text { Chlorophyll } a \\
\left(\mathrm{mg} \mathrm{L}^{-1}\right)\end{array}$ & $19.13 \pm 2.6$ & $23.97 \pm 4$ & $28.46 \pm 3$ & $54.56 \pm 5$ & $5.95 \pm 3$ & $6.51 \pm 2.2$ & $18.82 \pm 3$ & $10.82 \pm 2$ & $8.58 \pm 3$ & $7.22 \pm 2.2$ \\
\hline TOC $\left(\mathrm{mg} \mathrm{L}^{-1}\right)$ & $27.4 \pm 4$ & $37.4 \pm 4$ & $44.5 \pm 3$ & $.1 \pm 4$ & $24.5 \pm 6$ & $25.1 \pm 4$ & $24.5 \pm 3$ & $25.8 \pm 3$ & $21.1 \pm 3$ & $18.3 \pm 4$ \\
\hline \multicolumn{11}{|c|}{ Central part } \\
\hline Water level $(\mathrm{cm})$ & $9 \pm 3$ & $17 \pm 4$ & $17 \pm 3$ & $22 \pm 2$ & $22 \pm 4$ & $32 \pm 4$ & $10 \pm 2$ & $15 \pm 3$ & $44 \pm 3$ & $39 \pm 4$ \\
\hline Temp. $\left({ }^{\circ} \mathrm{C}\right)$ & $13.5 \pm 3$ & $12.3 \pm 2$ & $8.4 \pm 3$ & $9.3 \pm 2$ & $9.0 \pm 3$ & $7.6 \pm 3$ & $8.8 \pm 1$ & $12.0 \pm 2$ & $12.0 \pm 2$ & $8.1 \pm 3$ \\
\hline $\mathrm{pH}$ & $8.1 \pm 1$ & $8.2 \pm 2$ & $8.4 \pm 1$ & $8.6 \pm 1$ & $8.2 \pm 1$ & $9.7 \pm 0.7$ & $8.5 \pm 2$ & $7.8 \pm 1$ & $7.5 \pm 0.4$ & $7.5 \pm 1$ \\
\hline Cond. $\left(\mu \mathrm{S} \mathrm{cm}^{-1}\right)$ & $282.3 \pm 23$ & $283.4 \pm 21$ & $172.4 \pm 11$ & $183.0 \pm 11$ & $183.0 \pm 23$ & $173.8 \pm 22$ & $208.9 \pm 11$ & $113.8 \pm 23$ & $109.6 \pm 21$ & $150.1 \pm 11$ \\
\hline $\mathrm{O}_{2}\left(\mathrm{mg} \mathrm{L}^{-1}\right)$ & $5.3 \pm 2$ & $4.8 \pm 2$ & $6.2 \pm 1$ & $9.4 \pm 2$ & $8.4 \pm 1$ & $8.7 \pm 2$ & $4.2 \pm 2$ & $9.2 \pm 1$ & $8.7 \pm 1$ & $7.7 \pm 1$ \\
\hline $\mathrm{NH}_{4}^{+}\left(\mathrm{mg} \mathrm{L}^{-1}\right)$ & $0.471 \pm 0.11$ & $0.471 \pm 0.12$ & $0.571 \pm 0.11$ & $0.577 \pm 0.12$ & $0.464 \pm 0.13$ & $0.361 \pm 0.11$ & $0.561 \pm 0.13$ & $0.364 \pm 0.23$ & $0.182 \pm 0.03$ & $0.049 \pm 0.03$ \\
\hline $\mathrm{NO}_{3}^{-}\left(\mathrm{mg} \mathrm{L}^{-1}\right)$ & $0.262 \pm 0.07$ & $0.123 \pm 0.08$ & $0.280 \pm 0.03$ & $0.225 \pm 0.12$ & $0.125 \pm 0.11$ & $0.125 \pm 0.11$ & $0.225 \pm 0.054$ & $0.225 \pm 0.08$ & $0.159 \pm 0.09$ & $0.149 \pm 0.07$ \\
\hline $\mathrm{N}_{\mathrm{tot}}\left(\mathrm{mg} \mathrm{L}^{-1}\right)$ & $2.628 \pm 0.23$ & $2.628 \pm 0.23$ & $2.636 \pm 0.11$ & $1.614 \pm 0.23$ & $1.614 \pm 0.32$ & $1.614 \pm 0.45$ & $1.864 \pm 0.23$ & $1.864 \pm 0.08$ & $1.763 \pm 0.09$ & $1.306 \pm 0.23$ \\
\hline $\mathrm{PO}_{4}{ }^{3-}\left(\mathrm{mg} \mathrm{L}^{-1}\right)$ & $0.064 \pm 0.02$ & $0.018 \pm 0.01$ & $0.014 \pm 0.01$ & $0.057 \pm 0.012$ & $0.057 \pm 0.01$ & $0.057 \pm 0.02$ & $0.095 \pm 0.03$ & $0.095 \pm 0.03$ & $0.036 \pm 0.01$ & $0.049 \pm 0.01$ \\
\hline $\mathrm{P}_{\mathrm{tot}}\left(\mathrm{mg} \mathrm{L}^{-1}\right)$ & $0.244 \pm 0.03$ & $0.092 \pm 0.03$ & $0.087 \pm 0.03$ & $0.178 \pm 0.02$ & $0.190 \pm 0.05$ & $0.173 \pm 0.067$ & $0.215 \pm 0.07$ & $0.215 \pm 0.11$ & $0.141 \pm 0.09$ & $0.103 \pm 0.09$ \\
\hline $\begin{array}{l}\text { Chlorophyll } a \\
\left(\mathrm{mg} \mathrm{L}^{-1}\right)\end{array}$ & $16.88 \pm 6$ & $16.88 \pm 3$ & $14.72 \pm 2$ & $6.45 \pm 2$ & $5.94 \pm 2$ & $5.95 \pm 2$ & $13.82 \pm 4$ & $10.82 \pm 4$ & $11.25 \pm 3$ & $7.39 \pm 2$ \\
\hline TOC $\left(\mathrm{mg} \mathrm{L}^{-1}\right)$ & $28.9 \pm 3$ & $30.4 \pm 4$ & $37.8 \pm 2$ & $24.5 \pm 2$ & $27.3 \pm 3$ & $24.5 \pm 8$ & $24.5 \pm 3$ & $25.8 \pm 4$ & $19.3 \pm 2$ & $14.9 \pm 3$ \\
\hline
\end{tabular}

Tab. 3. Correlation matrix of measured environmental variables in lagg central zone transect in investigated fen.

\begin{tabular}{|c|c|c|c|c|c|c|c|c|c|c|c|c|}
\hline & WL & Temp. & $\mathrm{pH}$ & Cond. & $\mathrm{O}_{2}$ & $\mathbf{N}_{\text {tot }}$ & $\mathrm{NH}_{4}^{+}$ & $\mathrm{NO}_{3}^{-}$ & $\mathbf{P}_{\text {tot }}$ & $\mathrm{PO}_{4}{ }^{3-}$ & Chl- $a$ & TOC \\
\hline WL & 1 & ns & ns & $0.36^{*}$ & ns & ns & $-0.53 * *$ & ns & ns & ns & $0.28 *$ & $-0.41 * *$ \\
\hline Temp. & ns & 1 & $-0.29 *$ & $\mathrm{~ns}$ & $-0.33^{*}$ & ns & ns & $0.29 *$ & ns & ns & ns & ns \\
\hline $\mathrm{pH}$ & ns & $-0.29 *$ & 1 & $\mathrm{~ns}$ & $0.24 *$ & $-0.46 * *$ & ns & ns & ns & ns & ns & $-0.31 *$ \\
\hline Cond. & $0.36^{*}$ & ns & ns & 1 & $\mathrm{~ns}$ & ns & $\mathrm{ns}$ & $-0.35^{*}$ & ns & ns & ns & $-0.41 * *$ \\
\hline $\mathrm{O}_{2}$ & ns & $-0.33^{*}$ & $0.24 *$ & $\mathrm{~ns}$ & 1 & ns & $\mathrm{ns}$ & $0.25^{*}$ & ns & ns & ns & $\mathrm{ns}$ \\
\hline $\mathrm{N}_{\text {tot }}$ & ns & ns & $-0.46 * *$ & $\mathrm{~ns}$ & $\mathrm{~ns}$ & 1 & ns & ns & ns & ns & $0.25 *$ & ns \\
\hline $\mathrm{NH}_{4}^{+}$ & $-0.53 * *$ & ns & ns & $\mathrm{ns}$ & $\mathrm{ns}$ & ns & 1 & ns & ns & ns & ns & $\mathrm{ns}$ \\
\hline $\mathrm{NO}_{3}^{-}$ & ns & $0.29 *$ & $\mathrm{~ns}$ & $-0.35^{*}$ & $0.25^{*}$ & ns & $\mathrm{ns}$ & 1 & $0.35^{*}$ & $\mathrm{~ns}$ & $\mathrm{~ns}$ & $0.28 *$ \\
\hline $\mathrm{P}_{\text {tot }}$ & ns & ns & $\mathrm{ns}$ & $\mathrm{ns}$ & $\mathrm{ns}$ & ns & $\mathrm{ns}$ & $0.35^{*}$ & 1 & $0.44^{* *}$ & $\mathrm{~ns}$ & ns \\
\hline $\mathrm{PO}_{4}^{3-}$ & ns & $\mathrm{ns}$ & ns & $\mathrm{ns}$ & $\mathrm{ns}$ & ns & $\mathrm{ns}$ & ns & $0.44 * *$ & 1 & ns & $0.27 *$ \\
\hline Chl- $a$ & $0.28 *$ & ns & ns & $\mathrm{ns}$ & ns & $0.25 *$ & ns & ns & ns & ns & 1 & ns \\
\hline TOC & $-0.41 * *$ & ns & $-0.31^{*}$ & $-0.41 * *$ & ns & ns & ns & $0.28 *$ & ns & $0.27 *$ & ns & 1 \\
\hline
\end{tabular}

WL, water level; $* P<0.05 ; * * P<0.01 ;$ ns, not significant. 
TOC ( $r=0.56-74, \mathrm{P}<0.01$, respectively), $\mathrm{N}_{\text {tot }}(r=0.51-0.71$, $\mathrm{P}<0.01)$, chlorophyll $a$ concentration $(r=0.53-67, \mathrm{P}<0.01)$ and richness of plant species $(r=0.51-53, \mathrm{P}<0.01)$. Before restoration, the most common ciliates were Cinetochilum margaritaceum and Strombidium viride, while the proportion of Paramecium bursaria increased after restoration. The highest indicator values (IndVal) were found for C. margaritaceum (0.73), and $S$. viride (0.49). The best indicators of fens areas before restoration were P. bursaria, C. margaritaceum and Chilodonella uncinata. In contrast, the best indicators of restored fen were $S$. viride and Strombilidium spp. Ciliate abundance and biomass showed pronounced fluctuations between years. A higher abundance and biomass was recorded before restoration $\left(55 \pm 11\right.$ cells $\mathrm{mL}^{-1}$ and $\left.>0.6 \pm 0.2 \mu \mathrm{g} \mathrm{C} \mathrm{L}\right)$, while the average abundance and biomass after restoration was lower $\left(28 \pm 8\right.$ cells $\mathrm{mL}^{-1}$ and $\left.0.3 \pm 0.1 \mu \mathrm{gC} \mathrm{mL}^{-1}\right)$ $\left(\mathrm{F}_{1.41} 28.37, \mathrm{P} \leq 0.001, \mathrm{df}=5\right)$. In lagg habitat, densities of ciliates were significantly lower before than after restoration (ANOVA, $\mathrm{F}_{1.20} 1.21$ and $1.69, \mathrm{P}=0.031$ and $0.024, \mathrm{df}=5$ and $\mathrm{df}=6$, respectively) (Fig. 4). Prior to the restoration, bacterivorous scuticociliates had the highest share in the total abundance of ciliates, but after the restoration there was a pronounced increase in the share of mixotrophic oligotrichids and omnivorous pleurostomatids (Fig. 5). Benthic and periphytic taxa were dominant before restoration, while euplanktonic taxa increased after restoration (Tab. 4). The abundance of periphytic and benthic ciliates was positively related to the plant diversity index ( $r=0.53-0.42, \mathrm{P}<0.05$, respectively). The number of euplanktonic ciliates and their abundance showed a negative relationship with the vegetation diversity index $(r=-0.33-0.39, \mathrm{P}<0.05)$.

\section{Ciliates vs environmental parameters}

PCA axis $1(\lambda=0.784)$ and axis $2(\lambda=0.058)$ explained $84.2 \%$ of the total variance in the composition of ciliates in the lagg. The distribution of samples on the ordination plot in such a way that samples taken in 2005 and samples taken in 2014 are situated at extreme positions, suggesting continuous changes in the ciliates' community after restoration (Fig. 6A). The length of the variability gradient and position on the graph of $C$. uncinata and $C$. margaritaceum show that these species had high densities in the lagg habitat before restoration. The restoration procedures caused pronounced changes in the species structure of Ciliata. The species Aspidisca cicada, Amphileptus cleparedei, Coleps hirtus, Euplotes sp., Lacrymaria olor, Stylonychia mytilus complex, $P$. bursaria and Prorodon sp. were more abundant before restoration. After the restoration, the share of Codonella cratera, Coleps spetai, Drepanomonas revoluta, Holosticha pullaster, Paradileptus elephantinus and Spathidium sensu lato increased. At the end of the study period (2012-2014), S. viride and Strobilidium sp. were dominant species in the lagg habitat (Fig. 6B). PCA analysis performed for samples taken in the central part of the fen revealed a clear separation of the samples into

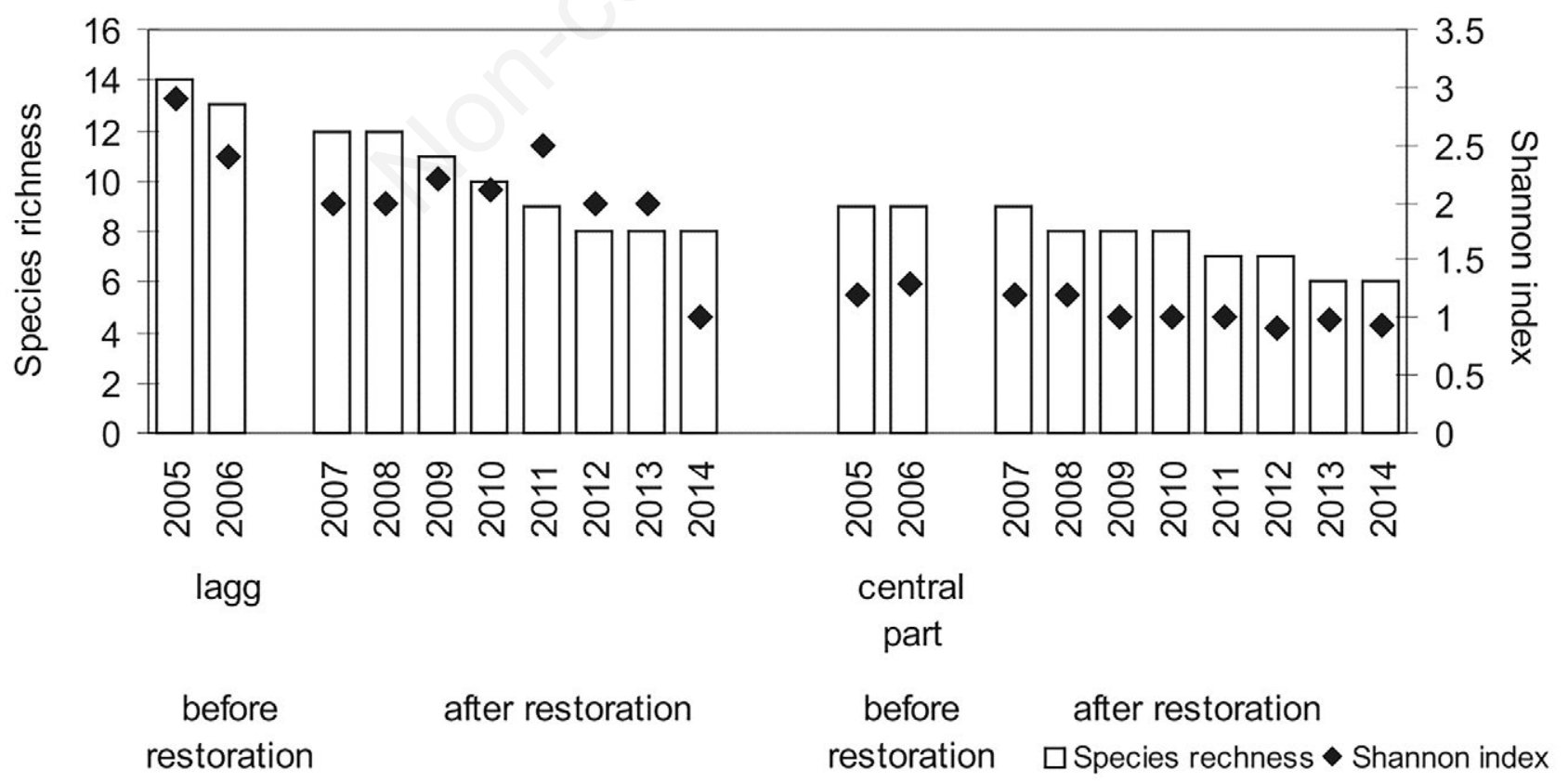

Fig. 2. Changes in species richness and Shannon index of ciliates before and after restoration of fen. 
three groups: those collected in 2005-2008, 2009-2011, and 2012-2014 (Fig. 6C). The distribution of Ciliata species on the ordination plot suggests changes in species structure from dominance of $A$. claparedii, C. uncinata, C. margaritaceum and L. olor in 2005-2008 to dominance of S. viride and Strobilidium sp. in 2012-2014 (Fig. 6D). In general, PCA axis $1(\lambda=0.844)$ and axis $2(\lambda=0.066)$ explained $91 \%$ of the total variance in the composition of ciliates in the central part of the fen.

Redundancy analysis performed for the lagg samples collected before restoration showed that all variables together explained $86.9 \%$ of the total variance of ciliates. Three variables had a significant: WL $(\mathrm{P}=0.024), \mathrm{pH}$ $(\mathrm{P}=0.048)$, and chl- $a(\mathrm{P}=0.032)$ and each of them explained from $10 \%$ (chl- $a$ and $\mathrm{pH}$ ) to $18 \%$ (WL) of the total variance in Ciliata. On the RDA biplot the abundance of $S$. viride and $P$. bursaria were affected by chl- $a$, whereas the abundance of $C$. cratera, $C$. cucullus, $H$. pullaster, S. sensu lato, Prorodon sp., P. elephantinus and $S$. mytilus increased with $\mathrm{pH}$. An analysis of the relationships between WL and ciliate species, including A. claparedii, C. spetai, D. revoluta, S. ambiguum, Strobilidium sp. and Euplotes sp., suggests that the abundance of these ciliates increased together with increases in WL (Fig. 7A). Environmental variables had a smaller influence on the presence and density of ciliates in the restored lagg, as they explained $61.1 \%$ of the total variance in Ciliata. Five variables had a significant effect, i.e. $\mathrm{WL}(\mathrm{P}=.004)$, temperature $(\mathrm{P}=0.002), \mathrm{EC}(\mathrm{P}=0.002)$,
$\mathrm{N}-\mathrm{NH}_{4}(\mathrm{P}=0.002)$, and $\mathrm{N}_{\text {tot }}(\mathrm{P}=0.01)$, and each of them explained from $3 \%\left(\mathrm{~N}_{\text {tot }}\right)$ to $27 \%(\mathrm{EC})$ of the total variance in Ciliata. On the RDA biplot the presence of D. revoluta, P. elephantinus and Spathidium sensu lato showed a relationship with $\mathrm{EC}$ and $\mathrm{N}_{\text {tot }}$. The abundance of $C$. hirtus, C. uncinata, L. olor, C. margaritaceum, C. cratera, $H$. pullaster, $S$. ambiguum, and $S$. mytilus complex was correlated with $\mathrm{N}-\mathrm{NH}_{4}$. The location of temperature and $\mathrm{WL}$ on the RDA biplot showed that these variables were negatively correlated with $\mathrm{N}-\mathrm{NH}_{4}$, thus suggesting a

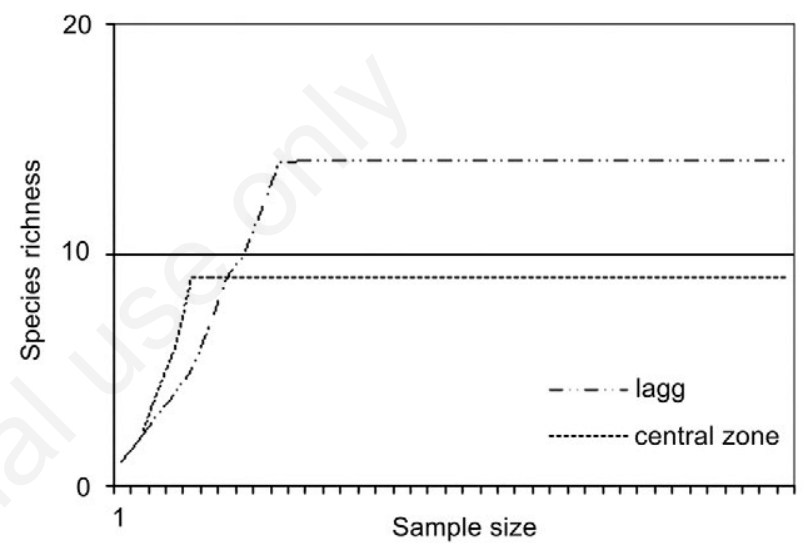

Fig. 3. Rarefaction plot of species richness in lagg $v s$ central zone of fen.

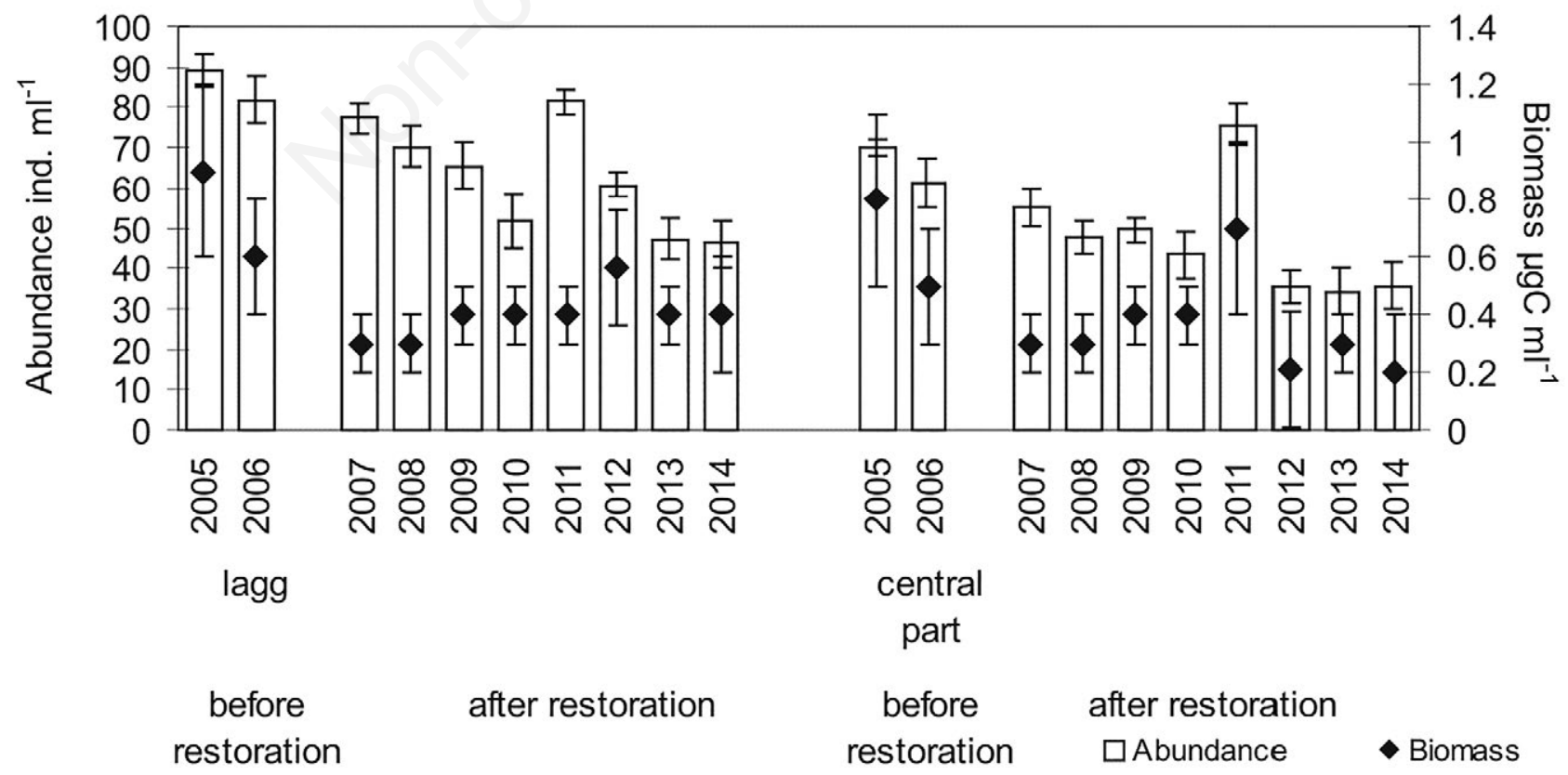

Fig. 4. Changes in numbers and biomass of ciliates before and after restoration of fen. $\mathrm{T} S \mathrm{D}$, standard deviation. 
negative influence of temperature and $\mathrm{WL}$ on Ciliata correlated with $\mathrm{N}^{-\mathrm{NH}_{4}}$ (Fig. 7B). Before restoration, environmental variables explained $77.8 \%$ of the total variance in Ciliata in the central part of the fen. Three variables had a significant effect, i.e. WL $(\mathrm{P}=0.016), \mathrm{pH}$ $(\mathrm{P}=0.004)$ and chl $-a(\mathrm{P}=0.03)$, and each of them explained from $13 \%(\mathrm{chl}-a)$ to $31 \%(\mathrm{pH})$ of the total variance in Ciliata. On the RDA biplot the presence of $D$. revoluta, and $L$. olor showed a relationship with chl- $a$. The $\mathrm{pH}$ influenced the abundance of $P$. elephantinus, Spathidium sensu lato and Prorodon sp., whereas increased WL coincided with increased abundances of $S$. ambiguum, $A$. claparedii, C. margaritaceum, A. cicada and Euplotes sp. (Fig. 7C). The restoration processes altered the relationships between ciliates and environmental variables. Overall, all environmental variables explained $53.5 \%$ of the variance in Ciliata in the central part of the fen after restoration. The Monte Carlo permutation test showed a significant influence of EC ( $\mathrm{P}=0.002), \mathrm{WL}$ $(\mathrm{P}=0.002), \mathrm{N}_{\text {tot }}(\mathrm{P}=0.022)$ and temperature $(\mathrm{P}=0.042)$, which explained from $3 \%$ (temperature and $\mathrm{N}_{\text {tot }}$ ) to $29 \%$ (EC) of the total variance in Ciliata. On the ordination biplot, A. claparedii, C. cucullus, C. uncinata, and L. olor showed a positive relationship with $\mathrm{N}_{\text {tot }}$. The presence of D. revoluta, P. elephantinus and Spathidium sensu lato was affected by EC. The location of a group of species on the ordination plot, including C. spetai, C. hirtus, C. cratera, C. margaritaceum, P. bursaria, S. ambiguum and S. mytilus complex suggest their negative correlation to WL and temperature (Fig. 7D).

\section{DISCUSSION}

\section{Effects of restoration on environmental factors}

The restoration procedures caused a raising of the water level, irrespective of the kind of habitats. At the beginning of the restoration period, a marked increase in the $\mathrm{pH}$ and electrolytic conductivity and a decrease in oxygen content were observed as well. The $\mathrm{pH}$ values were much lower in the lagg zone, probably due in part to the presence in the water of humic acids arising during oxidation of organic detritus (Górniak et al., 1999). The rise of $\mathrm{pH}$ values after restoration also supports this statement, since this variable increases if respiration rates and humic compounds decrease and it can also reflect variation in primary production (Wetzel, 2001). At the same time, at the start of the restoration an increase in the concentration of biogenic compounds and total organic carbon was observed, which may be an indicator of the destabilization of habitat conditions. This was mainly due to decomposition of vegetation, including shrubs and trees

Tab. 4. Ciliate species found in investigated peatbog, their preferred habitats and trophic group.

\begin{tabular}{|c|c|c|c|}
\hline Taxa & Ecological groups & Functional groups & Dominance period \\
\hline Amphileptus claparedii Stein, 1867 & $\mathrm{P}$ & $\operatorname{Pr}$ & $\mathrm{BR}$ \\
\hline Aspidisca cicada Dujardin, 1841 & $\mathrm{P}$ & $\mathrm{Ba}$ & BR \\
\hline Chilodonella uncinata Ehrenberg, 1838 & $\mathrm{P}$ & $\mathrm{Ba}$ & $\mathrm{AR}$ \\
\hline Cinetochilum margaritaceum Perty, 1852 & EU & $\mathrm{Ba}$ & $\mathrm{BR}$ \\
\hline Codonella cratera Leidy, 1877 & EU & $\mathrm{Al}$ & $\mathrm{AR}$ \\
\hline Coleps hirtus Müller, 1786 & EU & $\mathrm{O}$ & $\mathrm{BR}$ \\
\hline Coleps spetai Foissner, 1984 & EU & $\mathrm{O}$ & $\mathrm{AR}$ \\
\hline Colpoda cucullus Müller, 1773 & $P$ & $\mathrm{Ba}, \mathrm{Al}$ & $\mathrm{AR}$ \\
\hline Drepanomonas revoluta Penard, 1922 & $P$ & $\mathrm{Ba}$ & $\mathrm{AR}$ \\
\hline Euplotes sp. & $\mathrm{B}$ & $\mathrm{Ba}$ & $\mathrm{BR}$ \\
\hline Holosticha pullaster Müller, 1773 & B & $\mathrm{Ba}, \mathrm{Al}$ & $\mathrm{AR}$ \\
\hline Lacrymaria olor Müller, 1776 & $\mathrm{~B}$ & $\operatorname{Pr}$ & $\mathrm{BR}$ \\
\hline Paradileptus elephantinus Kahl, 1931 & $\mathrm{P}$ & $\mathrm{O}$ & $\mathrm{AR}$ \\
\hline Paramecium bursaria Ehrenberg, 1831 & $\mathrm{P}$ & $\mathrm{Ba}, \mathrm{Al}$ & $\mathrm{AR}$ \\
\hline Prorodon sp. & $\mathrm{B}$ & $\operatorname{Pr}$ & $\mathrm{BR}$ \\
\hline Strombidium viride Stein, 1867 & EU & $\mathrm{Al}$ & AR \\
\hline Spirostomum ambiguum Müller, 1786 & $\mathrm{~B}$ & $\mathrm{Ba}$ & $\mathrm{AR}$ \\
\hline Spathidium sensu lato & $\mathrm{P}$ & $\operatorname{Pr}$ & $\mathrm{AR}$ \\
\hline Strobilidium spp. & EU & $\mathrm{Al}$ & $\mathrm{AR}$ \\
\hline Stylonychia mytilus Ehrenberg, 1838 & $\mathrm{P}$ & $\mathrm{O}$ & $\mathrm{BR}$ \\
\hline
\end{tabular}

EU, euplanktonic; $B$, benthic; $P$, periphytic; Ba, bacterivorous; $O$, omnivorous; Al, algivorous; $P$, predators; BR, before restoration; AR, after restoration. 
that were cut down but not immediately removed. The concentrations of biogenic compounds, on the other hand, dropped substantially in the open fen. They probably originated (especially phosphates) in the waters of the forest catchment area, which can partially feed the fen, while the lagg zone can partially trap them and act as a 'biofilter'. Wardle et al. (2012) reported that increased N deposition might increase mineralization, increasing the supply of $\mathrm{P}$ to the plants; therefore, growth of plants may be as much due to the indirect effect of increased availability of $\mathrm{P}$, as well as the direct effect of $\mathrm{N}$ deposition. The lower oxygen concentration observed before and two years after restoration was probably due to its high consumption by the large amount of organic matter (high decomposition rate) and humic compounds (Scheffer, 2004), which were accumulated in the sediment before restoration, when emergent vegetation was very abundant.

\section{Effects of restoration on ciliate composition and abundance}

Irrespective of the zone of the fen, the number of ciliate taxa was higher before restoration, and it increased with the water level and the concentration of nutrients and total organic carbon in the water. Such relationships have also been observed in various types of wetlands in 'mesocosm' systems in which concentrations of biogenic compounds were manipulated (Mieczan et al., 2015). Bobrov et al. (1999) observed a clear increase in species diversity of testate amoebae in wet microhabitats. Favourable hydrological conditions also occurred after restoration. In Greek peatbogs, Payne and Mitchell (2007) emphasised the significant influence of the level of the groundwater table and $\mathrm{pH}$ on occurrence of the testate amoebae. Such a relation also exists in the wetland studied in ciliate communities. Buosi et al. (2011) also observed that the species richness of ciliates increases with habitat fertility. Such pronounced changes in ciliate communities are probably associated with their life cycle and structure. Their generation times are short, and they are only protected from the environment by a delicate cell membrane. Therefore, the potential response time to environmental changes is fast (Buosi et al., 2011; Andersen et al., 2013). The number of ciliates was markedly higher before the restoration procedures and increased together with the concentrations of chlorophyll $a$ and biogenic compounds in the water. The increase in concentrations of chlorophyll $a$ and biogenic compounds may have caused changes in the abundance of potential food for the protozoa, especially algae. Nutrient enrichment caused a change in dominance from the smallsized Cosmarium to the large-sized Netrium (desmids), as

\section{血Bacterivorous $\quad$ Algivorous $\quad \square$ Omnivorous $\quad$ Predatory Mixotrophic}

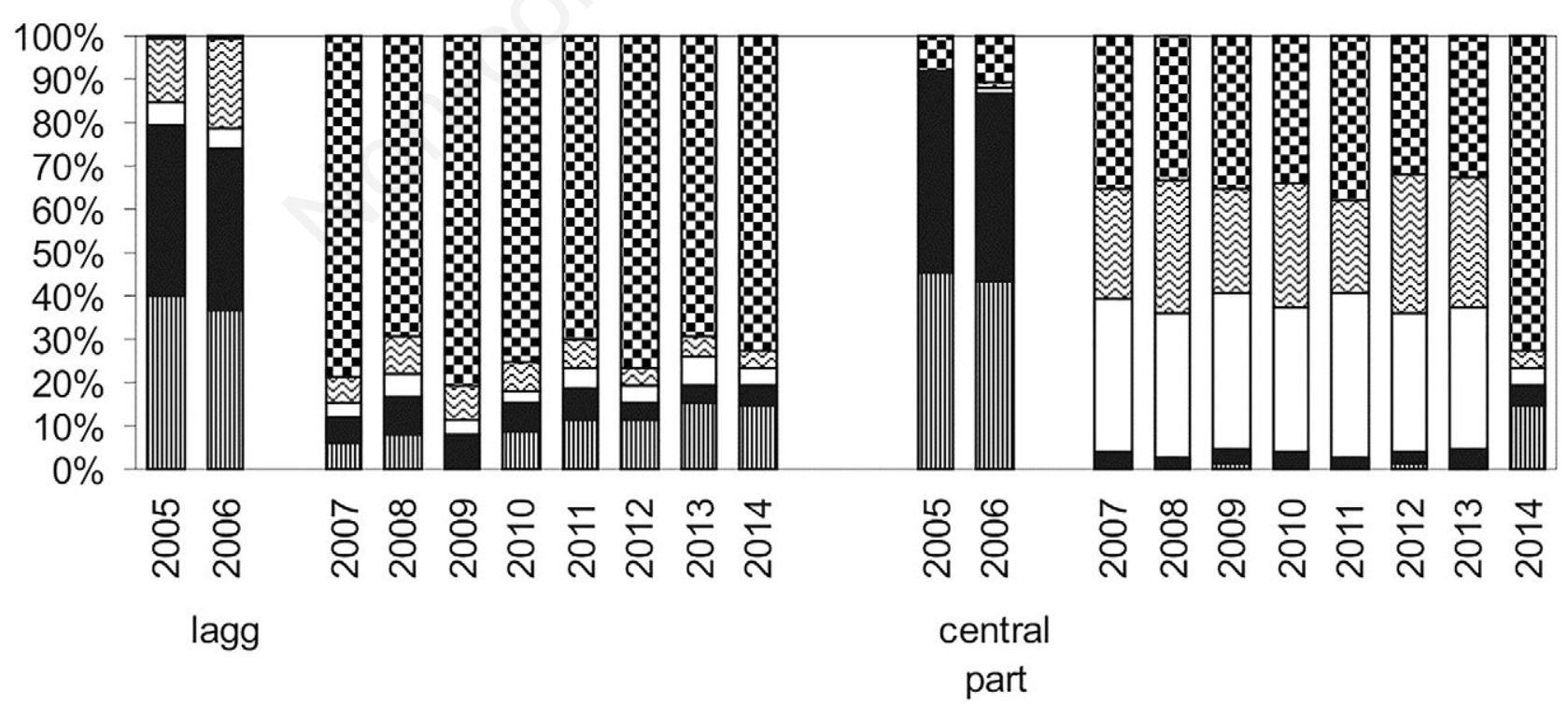

before after restoration
restoration

\section{before restoration}

after restoration

Fig. 5. Changes in percentage contribution of trophic group of ciliates before and after restoration of fen. 
well as an increase in the proportion of small cyanobacteria (Mataloni, 1999). Of the factors studied thus far, temperature and food have been found to have the strongest impact on the growth rates of ciliate populations. The overwhelming importance of food resources and temperature has been confirmed with several freshwater prostome and oligotrich species (Weisse et al., 2002; Weisse, 2006). On the other hand, temperature is positively correlated with the rate of bacterial reproduction (Chróst and Siuda, 2006), which may improve food conditions for ciliates. It also seems that the restoration measures significantly altered the microhabitat conditions in both the lagg zone and the central part of the fen, probably due mainly to the higher water level. This modification of the microhabitat is also reflected in changes in the percentage share of individual ecological groups of ciliates in their total number. Prior to restoration, mainly benthic taxa were dominant, but after restoration the share of periphyton taxa and euplanktonic grew, varying between zones of the fen. In our study, euplanktonic taxa were dominant in the central part of the fen, mainly in belts of emergent plants, while periphytic taxa increased in the lagg. The number of euplanktonic taxa and their abundance showed a negative relationship with the vegetation diversity index, while the corresponding relationships for benthic and periphytic ciliates were positive. This clearly shows that high diversity of plants in fens favours benthic and periphytic ciliates. Variation in the taxonomic composition, abundance and proportions of individual ecological groups between belts of vegetation is relatively well known in the case of planktonic rotifers and crustaceans in lake ecosystems (Hann, 1995). In the present study, the diversity, abundance and biomass of ciliate species were all observed to increase with the density of the fen vegetation and the complexity of its spatial structure. This was especially evident after the restoration in the microhabitats where Calliergonella began to grow.
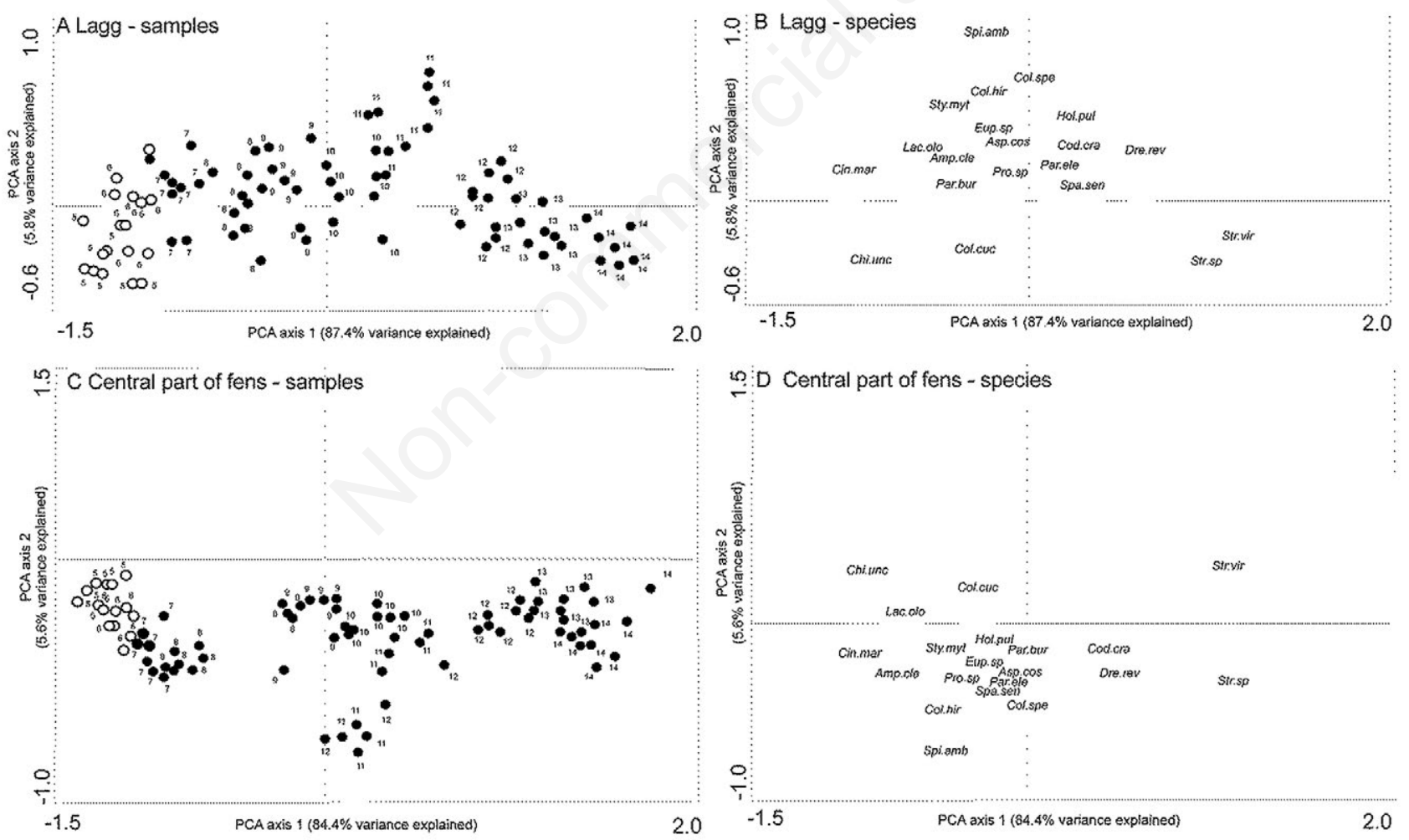

Fig. 6. Principal component analysis (PCA) biplots for axes 1 and 2 showing inter-taxonomic correlations (a) in the lagg (b) and intertaxonomic correlations (c) in the central part of fens (d). Samples marked with o correspond to those collected before restoration, and samples marked with $\bullet$ correspond to those collected after restoration; numbers 5-14 correspond to years 2005-2014. Species codes for Ciliata: Amp.cle-Amphileptus claparedii, Asp.cos-Aspidisca cicada, Chi.unc-Chilodonella uncinata, Cin.mar-Cinetochilum margaritaceum, Cod.cra - Codonella cratera, Col.hir - Coleps hirtus, Col.spe - Coleps spetai, Col.cuc - Colpoda cucullus, Dre.revDrepanomonas revoluta, Eup.sp - Euplotes sp., Hol.pul - Holosticha pullaster, Lac.olo - Lacrymaria olor, Par.ele - Paradileptus elephantinus, Par.bur - Paramecium bursaria, Pro.sp - Prorodon sp., Spa.sen - Spathidium sensu lato, Spi.amb - Spirostomum ambiguum, Str.vir - Strombidium viride, Str. sp - Strobilidium spp., Sty.myt - Stylonychia mytilus. 
Kuczyńska-Kippen (2005) and Warfe and Barmuta (2006) showed that the denser and more morphologically complex a belt of plants is, the more diverse invertebrates' communities are in terms of qualitative and quantitative structure. Therefore, most structurally complex vegetation is more attractive to ciliates, providing a greater food supply and a safe refuge. At the same time, among the patches of Utricularia and Calliergonella (in the lagg zone), significantly higher concentrations of total phosphorus total and organic carbon were found, which
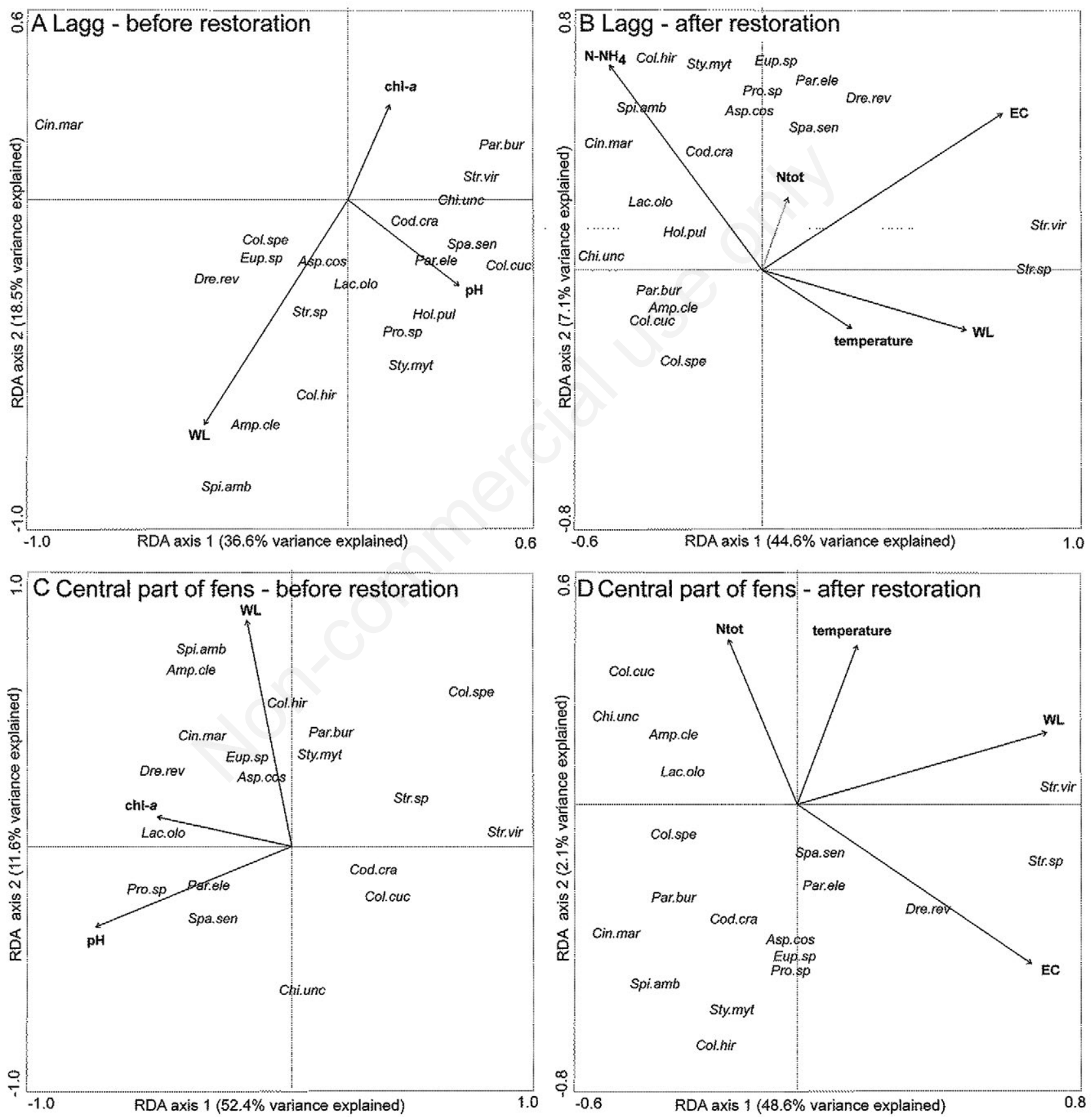

Fig. 7. Redundancy analysis (RDA) biplots showing correlations between studied communities and environmental variables in the lagg before restoration (a) and after restoration (b) as well central part of fens before restoration (c) and after restoration (d). Solid arrows indicate significant parameters in Monte Carlo permutation test at $\mathrm{P}<0.05$. Significant variables $(\mathrm{P}<0.05)$ were presented as black bold arrows on the diagrams. Species codes for Ciliata as in Fig. 5. 
could indirectly affect the abundance of food. This may explain the exceptional abundance of ciliates in the patches analysed. This relationship is confirmed by the dominance of small, mainly bacterivorous and algivorous taxa. A study conducted by Sirová et al. (2009) indicates exceptional abundance of bacteria and algae in patches of Utricularia. In the investigated fen, a substantial transformation in the dominance structure of ciliates occurred at the end of the study - from Scuticociliates, dominant before restoration, to Oligotrichids. Oligotrichida occurred in large numbers in a microenvironment with an appreciable level of nutrients and a higher water level (Mieczan, 2009). However, the contribution of Scuticociliatada (C. margaritaceum) increased with the level of nutrients and $\mathrm{pH}$. Due to their small size, they are predisposed to easier movement and a higher rate of reproduction, and thus colonization of new habitats. According to literature data (Buosi et al., 2011), these species have been observed many times in the earliest stages of ecosystem succession and are considered to be $r$ - strategists. Scuticociliatida as a rule occur numerously in eutrophic waters and are also observed in humic lakes, as well as in peatbog ecosystems (Mieczan, $2007,2009)$. The results of the RDA analysis showed that P. elephantinus, D. revoluta, S. ambiguum, S. mytilus, $H$. pullaster, C. hirtus, Ch. uncinata and C. cratera, and were associated with nutrients and water levels. Such species can potentially be considered indicators of eutrophic environments and/or hydrological parameters. The autecology of many species living in investigated fen corresponds well to published data (Jassey et al., 2010). In the wettest microhabitats with low $\mathrm{pH}$ species such as $S$. viride, and C. cratera were present, and in the driest ones are species such as Ch. uncinata and Colpidium. The genus Paramecium is often reported as characteristic of high-pH habitats.

\section{Effects of restoration on functional groups of ciliates}

The trophic structure of the ciliates clearly differed before and after restoration. Mainly algivorous and bacterivorous (A. cicada, C. margaritaceum) taxa were dominant before the restoration, while after restoration the proportion of mixotrophic (P. bursaria containing endosymbiotic Chlorella) and omnivorous taxa (P. elephantinus, $C$. spetai) increased. This change in the trophic structure of protozoa could be the effect of the modification of the physical and chemical properties of the microhabitat, or it may have resulted from the impact of organisms from higher trophic levels on ciliate communities. The microscopic observations showed that after the restoration procedures there was a marked increase in the share of rotifers, which could selectively consume small bacterivorous ciliates. Rotifers usually consume particles ranging in size from 0.5 to $20 \mu \mathrm{m}$
(Rothhaupt, 1990). According to Weisse and Frahm (2002) rotifer predation on ciliates can be species specific. Changes in the abundance of individual ciliate taxa may also have resulted from trophic interactions within this group of organisms. Research conducted by Jürgens et al. (1999) showed that the abundance of small ciliate species such as Halteria may be successfully controlled by large predatory species. Mieczan et al. (2015) also showed that large predatory or omnivorous ciliates (P. elephantinus) may control the abundance of small-sized taxa. Thus, it appears that the restoration measures also significantly modified the trophic structure of the ciliates. Furthermore, in the edge zone of the fen, in microhabitats dominated by brown mosses, obligate mixotrophic species of ciliates were found in high numbers, including Paramecium bursaria. These species containing endosymbiotic Chlorella and dominated in the central part of the fen, where brown mosses were present mainly in places shaded by Cladium mariscus and Phragmites australis. Studies on protozooplankton, however, have shown a marked increase in the proportion of mixotrophic taxa in habitats with low trophic status, while the proportion of heterotrophic taxa increased with trophic status (Saad et al., 2013). This pattern was also observed in our study, in which the share of mixotrophic taxa increased after restoration, while heterotrophic species had been dominant before restoration. According to Jassey et al. (2013) protists may exploit endosymbiotic algae as a potential energy source.

\section{CONCLUSIONS}

As a result of the restoration procedures, irrespective of the part of the fen examined, there was a clear improvement in hydrological conditions, an increase in $\mathrm{pH}$ and electrolytic conductivity, and over time a drop in concentrations of biogenic compounds as well. Throughout the study period, however, there were pronounced fluctuations in these properties. The study indicates that ciliates are highly suitable as bioindicators in assessing the effectiveness of restoration measures mainly in evaluation of the trophic conditions of fen. Our research indicates that $A$. claparedii, A. costata, $C$. cratera, C. steinii, P. elephantinus, P. nasuta, Prorodon sp., S. ambiguum, S. mytilus, and Spathidium sensu lato were associated with nutrients and may be indicators of eutrophic environments. On the other hand, P. bursaria and $S$. viride may be indicators of improvement in hydrological conditions in carbonate fens. Our results also suggest an indicator species approach based on functional and ecological (euplanktonic, benthic and periphytic) groups may be appropriate for biomonitoring fens restoration. The structure of ciliate communities in carbonate fens ecosystems subjected to restoration is still 
very poorly understood, but this knowledge is essential for understanding the functioning of these habitats.

\section{ACKNOWLEDGMENTS}

This work was funded in part under project N304 209837 by the Ministry of Science and Higher Education and project $2012 / 05 / \mathrm{B} / \mathrm{NZ} 8 / 01263$ by the National Science Centre, Poland.

\section{REFERENCES}

Andersen R, Wells C, Macrae M, Price J, 2013. Nutrient mineralization and microbial functional diversity in a restored bog approach natural conditions 10 years post restoration. Soil Biol. Biochem. 64:37-47.

Bayley S, Thormann MN, Szumigalski AR, 2005. Nitrogen mineralization and decomposition in western boreal bog and fen peat. Ecosci. 12:455-465.

Bragazza L, Freeman C, Jones T, Rydin H, Limpens J, Fenner N, Ellis T, Gerdol R, Hàjek M, Iacumin P, Kutnar L, Tahyanainen T, Toberman H, 2006. Atmospheric nitrogen deposition promotes carbon loss from peat bogs. P. Natl. Acad. Sci. USA 103:19386-19389.

Bobrov AB, Charman DJ, Warner BG, 1999. Ecology of Testate Amoebae (Protozoa: Rhizopoda) on peatlands in Western Russia with special attention to niche separation in closely related taxa. Protistol 150:125-136.

Buosi PRB, Pauleto GM, Lansac-Toha FA, Velho LFM, 2011. Ciliate community associated with aquatic macrophyte roots: effects of nutrient enrichment on the community composition and species richness. Eur. J. Protistol. 47: 86-102.

Chróst RJ, Siuda W, 2006. Microbial production, utylization, and enzymatic degradation of organic matter in the upper trophogenic layer in the pelagial zone of lakes along a eutrophication gradient. Limnol. Oceanogr. 5:749-762.

Creevy AL, Andersen R, Rowson JG, Payne RJ, 2018. Testate amoebae as functionally significant bioindicators in forestto-bog restoration. Ecol. Indic. 84:274-282.

Dufrene M, Legendre P, 1997. Species assemblages and indicator species: the need for a flexible asymmetrical approach. Ecol. Monogr. 67:345-366.

Elliott DR, Caporn SJM, Nwaishi F, Nilsson RH, Sen R, 2015. Bacterial and fungal communities in a degraded ombrotrophic peatland undergoing natural and managed revegetation. PLoS ONE 10:e0124726.

European Commission, 2013. Interpretation manual of European Union habitats, 2013 - EUR 28. European Commission DG Env. Available from: http://ec.europa.eu/environment/ nature/legislation/habitatsdirective/docs/Int_Manual_EU28. pdf

Foissner W, Berger H, 1996. A user-friendly guide to the ciliates (Protozoa, Ciliophora) commonly used by hydrobiologists as bioindicators in rivers, lakes and waste waters, with notes on their ecology. Freshwater Biol. 35:375-470.

Foissner W, Berger H, Kohmann F, 1994. [Taxonomische und ökologische Revision der Ciliaten des Saprobiensystems.
Hymenostomatida, Prostomatida, Nassulida].[Report in German]. Landesamt für Wasserwirtschaft, München.

Foissner W, Berger H, Schaumburg J, 1999. Identification and ecology of limnetic plankton ciliates. Landesamtes für Wasserwirtschaft, München.

Gilbert D, Amblard C, Bourdier G, Francez AJ, 1998a. The microbial loop at the surface of a peatland: structure, functioning and impact of nutrients inputs. Microb. Ecol. 35:89-93.

Gilbert D, Amblard C, Bourdier G, Francez AJ, 1998b. Shortterm effect of nitrogen enrichment on the microbial communities of a peatland. Hydrobiologia 373:111-119.

Golterman HL, 1969. Methods for chemical analysis of freshwaters. Blackwell Scientific Publications, Oxford, Edinburgh.

Górniak A, Jakatierynczuk-Rudczyk E, Dobrzyń P, 1999. Hydrochemistry of three dystrophic lakes in northeastern Poland. Acta Hydrachem. Hydrobiol. 27:12-18.

Gotelli NJ, Graves GR, 1996. Null models in ecology. Smithsonian Institution Press, Washington: $368 \mathrm{pp}$.

Gotelli N, Colwell RK, 2001. Quantifying biodiversity: Procedures and pitfalls in the measurement and comparison of species richness. Ecol. Lett. 4:379-391.

Gotelli NJ, Entsminger GL, 2004. EcoSim: Null models software for ecology. Ver. 7. Acquired Intelligence Inc. \& Kesey-Bear, Jericho. Available from: http://www.uvm.edu/ ngotelli/EcoSim/EcoSim.html

Hann BJ, 1995. Invertebrate associations with submersed aquatic plants in a prairie wetland. UFS (Delta Marsh) Annual Report 30:78-84.

Headley AD, Wheeler BD, Baker AJM, 1992. The impact of man on vegetation of Crymlyn bog, p. 257-261. In: O.M. Bragg, P.D. Hulme, H.A.P. Ingram and R.A. Robertson (eds.), Proceedings of the British Ecological Society/ International Peat Society Conference Peatland Ecosystems and Man: an impact assessment. University of Dundee/ International Peat Society, Dundee.

Jassey VEJ, Chiapusio G, Mitchell EAD, Binet P, Toussaint ML, Gilbert D, 2010. Fine-scale horizontal and vertical microdistribution patterns of testate amoebae along a narrow fen/bog gradient. Microb. Ecol. 2:374-385.

Jassey VEJ, Meyer C, Dupuy Ch, Bernard N, Mitchell EAD, Toussaint ML, Metina A, Chatelain P, Gilbert D, 2013. To what extent do food preferences explain the trophic position of heterotrophic and mixotrophic microbial consumers in a Sphagnum peatland. Microb. Ecol. 66:571-580.

Jürgens K, Skibbe O, Jeppesen E, 1999. Impact of metazooplankton on the composition and population dynamics of planktonic ciliates in a shallow, hypertrophic lake. Aquat. Microb. Ecol. 17:61-75.

Karus K, Feldmann T, Nõges P, Zingel P, 2014. Ciliate communities of a large shallow lake: association with macrophyte beds. Eur. J. Protistol. 50:382-394.

Kuczyńska-Kippen N, 2005. On body size and habitat selection in rotifers in a macrophyte-dominated lake Budzyńskie, Poland. Aquat. Ecol. 39:477-454.

Marcisz K, Fournier B, Gilbert D, Lamentowicz M, Mitchell EAD, 2014. Response of Sphagnum peatland testate amoebae to a 1 year transplantation experiment along an artificial hydrological gradient. Microb. Ecol. 67:810-818. 
Marker AFH, Nusch A, Rai H, 1980. The measurement of photosynthetic pigments in freshwater and standardization of methods: conclusions and recommendation. Arch. Hydrobiol. Beih. Ergebn. Limnol. 14:91-106.

Mataloni G, 1999. Ecological studies on algal communities from Tierra del Fuego peat bogs. Hydrobiologia 391:157-170.

McCormac JS, Schneider GH, 1994. Floristic diversity and of a disturbed western Ohio fen. Rhodora 96:327-353.

Mieczan T, 2007. Seasonal patterns of testate amoebae and ciliates in three peabogs: relationship to bacteria and flagellates (Poleski National Park, Eastern Poland). Ecohydrol. Hydrobiol. 1:79-88.

Mieczan T, 2009. Ciliates in Sphagnum peatlands: vertical micro-distribution, and relationships of species assemblages with environmental parameters. Zool. Stud. 48:33-48.

Mieczan T, Adamczuk M, Pawlik-Skowrońska B, Toporowska M, 2015. Eutrophication of peatbogs: consequences of $P$ and $\mathrm{N}$ enrichment for microbial and metazoan communities in mesocosm experiments. Aquat. Microb. Ecol. 74:121-141.

Mieczan T, Adamczuk M, Pogorzelec M, 2018. Ciliates as restoration indicators in peatbogs - 10 years of study. Eur. J. Protistol. 62:11-23.

Mieczan T, Bielańska-Grajner I, Tarkowska-Kukuryk M, 2012. Hydrochemical and microbiological distinction and function of ombrotrophic peatland lagg as ecotone between Sphagnum peatland and forest catchment (Poleski National Park, eastern Poland). Ann. Limnol. - Internat. J. Limnol. 48:323-336

Nguyen-Viet H, Gilbert D, Mitchell EAD, Badot PM, Bernard N, 2007. Effects of experimental lead pollution on the microbial communities associated with Sphagnum fallax (Bryophyta). Microb. Ecol. 54:232-241.

Oksanen J, Blanchet FG, Kindt R, Legendre P, Minchin PR, O'Hara RB, Simpson GL, Solymos P, Stevens MHH, Wagner H, 2012. Vegan: community ecology package. R package vegan, ver. 2.0-5. Accessed on: January 2017. Available from: http://vegan.r-forge.r-project.org

Payne RJ, Mitchell EAD, 2007. Ecology of testate amoebae from mires in the Central Rhodope Mountains, Greece and development of transfer function for paleohydrological reconstruction. Protist 158:159-171.

Pfister G, Auer B, Arndt H, 2002. Pelagic ciliates (Protozoa, Ciliophora) of different brackish and freshwater lakes - a community analysis at the species level. Limnologica 32:147-168.

Poulin M, Andersen R, Rochefort L, 2012. A new approach for tracking vegetation change after restoration: a case study with peatlands. Restorat. Ecol. 3:363-371.

R Core Team, 2013. R: A language and environment for statistical computing. $\mathrm{R}$ Foundation for Statistical Computing, Vienna, Austria.

Roberts DW, 2010. Ordination and multivariate analysis for ecology. Available from: https://rdrr.io/cran/labdsv/

Robson TM, Pancotto VA, Scopel AL, Flint SD, Caldwell M, 2005. Solar UV-B influences microfaunal community composition in a Tierra del Fuego peatland. Soil Biol. Biochem. 37:2205-2215.

Rothhaupt KO, 1990. Population growth rates of two closely related rotifer species: Effects of food quantity, particle size, and nutritional quality. Freshwater Biol. 23:561-570.

Saad JF, Schiaffino MR, Vinocur A, O’Farrell I, Tell G, Izaguirre I, 2013. Microbial planktonic communities of freshwater environments from Tierra del Fuego: dominant trophic strategies in lakes with contrasting features. J. Plankton Res. 6:1220-1233.

Shannon CE, Weaver W, 1949. The mathematical theory of communication. University Illinois Press, Urbana: 144 pp.

Scheffer M, 2004. Ecology of shallow lakes. Springer, Dordrecht: $380 \mathrm{pp}$.

Sirová D, Borovec J, Černá B, Rejmánková E, Adamec L, 2009. Microbial community development in the traps of aquatic Utricularia species. Aquat. Botany 90:129-136.

ter Braak CJF, Šmilauer P. 2002. CANOCO-FORTRAN program for Canonical Community Ordination (ver. 2.1). Microcomputer Power, Ithaca.

Utermöhl H, 1958. [Zur Vervollkommung der quantitative Phytoplankton-Methodik].[Article in German]. Mitt. Internat. Ver. Limnol. 9:1-38.

Venables WN, Ripley BD, 2002. Modern applied statistics with S. Springer, New York: 498 pp.

Wardle DA, Jansson M, Bansal S, Bardgett RD, Gundale MJ, Metcalfe DB, 2012. Linking vegetation change, carbon sequestration and biodiversity: insights from island ecosystems in a long-term natural experiment. J. Ecol. 100:16-30.

Warfe DM, Barmuta LA, 2006. Habitat structural complexity mediates food web dynamics in a freshwater macrophyte community. Oecologia 150:141-154.

Warner BG, Chmielewski JG, 1992. Testate amoebae (Protozoa) as indicators of drainage in a forested mire, Northern Ontario, Canada. Arch. Protistenkd. 141:179-183.

Weisse T, 2006. Freshwater ciliates as ecophysiological model organisms - lessons from Daphnia, major achievements, and future perspectives. Archiv. Hydrobiol. 167:371-402.

Weisse T, Frahm A, 2002. Direct and indirect impact of two common rotifer species (Keratella spp.) on two abundant ciliate species (Urotricha furcata, Balanion planctonicum). Freshwat. Biol. 1:53-64.

Weisse T, Stadler P, Lindstrőm ES, 2002. Interactive effect of temperature and food concentration on growth rate: a test case using the small freshwater ciliate Urotricha farcta. Limnol. Oceanogr. 47:1447-1455.

Wetzel RG, 2001. Limnology. Lake and river ecosystems. Academic Press, San Diego: 1006 pp.

Wilkinson DM, Mitchell EAD, 2010. Testate amoebae and nutrient cycling with particular reference to soils. J. Geomicrobiol. 27:520-533.

Wright AL, Reddy KR, Corstanje R, 2009. Patterns of heterotrophic microbial activity in eutrophic and oligotrophic peatlands. Soil Biol. 45:131-137. 